\title{
ANALISIS FUNDAMENTAL DAN TEKNIKAL DALAM PENGAMBILAN KEPUTUSAN UNTUK TRANSAKSI EMAS DI PERDAGANGAN BERJANGKA
}

\author{
Poppy Indriani dan Harjahdi \\ Fakultas Ekonomi, Universitas Bina Darma \\ e-mail : poppy_ucat@yahoo.com
}

\begin{abstract}
This study aims to analyze the factors that influence decision making in gold transactions in futures trading. Decision-making is done by using 2 analysis, the fundamental and technical analysis. Fundamental analysis is based on data from the economic and political news from the United States because of gold compared with USD. Meanwhile, the technical analysis performed using graphs and indicators (candlesticks, MACD and Stochastic). The results of both analyzes will indicate the direction of future price movements and assist in decision making for gold transactions will be done, either to sell or buy transactions. Decision-making is based on both the analysis of gold transactions will increase the chances of getting profit and reduce risk of loss.
\end{abstract}

Keywords: Fundamental, Technical, Buy, and Sell.

\section{PENDAHULUAN}

Pada masa sekarang ini perdagangan pada pasar berjangka mempunyai peranan yang sangat strategis dalam pembangunan ekonomi, terutama sebagai sarana pembentukan harga dan pelaksanaan lindung nilai. Peranan perdagangan berjangka dalam era globalisasi dan masa depan diperkirakan akan semakin penting dalam meningkatkan pertumbuhan ekonomi, karena persaingan pasar modal yang semakin tajam dan ketidakpastian kondisi ekonomi yang semakin meningkat.

Bagi para investor, kegiatan perdagangan berjangka, yang selanjutnya disebut perdagangan kontrak berjangka (future contract), dapat dijadikan pilihan investasi yang cukup menarik karena adanya factor leverage. Leverage adalah suatu keadaan dimana dengan penempatan sejumlah dana yang kecil dapat diperoleh keuntungan atau kerugian yang lebih besar sebagai akibat dari perubahan harga yang terjadi, yang besarnya diperhitungan dari nilai dana yang ditempatkan. Salah satu investasi yang menarik namun tergolong memiliki potential profit ( keuntungan) dan risk ( resiko) yang tinggi adalah dalam bentuk perdagangan komoditi emas yang dilakukan pada bursa berjangka.

Pasar berjangka yang lebih dikenal sebagai Bursa Berjangka memperdagangkan kontrak berjangka untuk berbagai komoditas, seperti pertanian, perkebunan, pertambangan, atau produk-produk keuangan seperti mata uang asing (foreign exchange), bahkan indeks seperti indeks saham (stock index).

Traksaksi emas merupakan suatu bentuk perdagangan yang melibatkan pasar uang utama dunia, mata uang yang diperdagangan setiap jam atas dasar global dan nilainya yang 
berubah hampir secara terus-menerus setiap detiknya. Karena banyak transaksi ekonomi yang berhubungan dengan transfer, pembelian, atau penjualan emas terhadap USD di masa mendatang, ketidakstabilan nilai tukar mendorong sejumlah ketidakpastian substansial dari transaksi-transaksi tersebut.

Perdagangan emas dalam perdagangan berjangka adalah perdagangan yang transaksinya dilakukan melalui kontrak beli dan atau kontrak jual dari komoditi yang diperdagangakan di bursa. Pengambilan keputusan dalam transaksi tersebut dapat menentukan potential profit (keuntungan) ataupun potential loss (kerugian) yang akan dialami ketika mengambil posisi membeli (buy) ataupun posisi menjual (sell).

Dalam semua bidang investasi, kemungkinan terjadinya resiko kerugian yang tidak diharapkan dalam pengambilan keputusan tersebut bisa saja terjadi. Karena pada dasarnya tidak ada satupun investasi yang sepenuhnya terbebas dari resiko.

Pelaku-pelaku ekonomi sangat dipengaruhi oleh ketidakpastian nilai tukar masa mendatang, misalnya : barang- barang yang diimpor yang diharapkan dapat di bayar dengan kurs yang lebih murah ketika jatuh tempo. Eksportir berharap menerima pembayaran dengan kurs yg lebih tinggi dari masa sewaktu barang di ekspor, pertukaran mata uang asing. Rencana-rencana portofolio investor untuk membeli dan menjual sekuritas-sekuritas dalam mata uang asing, pinjaman-pinjaman yang jatuh tempo untuk dibayarkan kembali tahun tahun yang akan datang. Individu-individu cenderung untuk berpergian ke luar negeri sampai pada kontrak-kontrak dan rencana-rencana investasi mengharuskan pelaku-pelaku ekonomi mempunyai pengetahuan tentang berapa kurs di masa yang akan datang.

Resiko kegagalan ada dalam setiap keputusan, dengan adanya ketidakpastian akan pergerakan harga yang akan terjadi, resiko pengambilan keputusan yang ada dalam setiap transaksi menjadi tinggi. Oleh karena itu diperlukan berbagai informasi atau analisis sebelum keputusan diambil dalam setiap transaksi, hal ini sangatlah penting untuk meminimalkan resiko karena pertumbuhan ekonomi dan perubahan aspek lain yang terjadi sangatlah cepat. Besar-kecilnya resiko tersebut antara lain tergantung pada kelengkapan informasi serta kualitas analisisnya sebelum keputusan diambil.

Oleh karena itu sebelum keputusan diambil dibutuhkan suatu analisis yang tepat. Faktor analisis yang dikenal untuk meminimalisasikan resiko kerugian dalam pengambilan keputusan dalam transaksi emas ada dua macam, yaitu Analisis Fundamental dan Analisis Teknikal.

Analisis fundamental dan teknikal dalam transaksi emas dapat mempengaruhi seorang trader untuk mengambil keputusan di perdagangan berjangka. Sehingga sangat penting untuk mengetahui faktor-faktor analisa apa saja yang dapat mempengaruhi pengambilan keputusan dalam transaksi forex di perdagangan berjangka.

\section{PERUMUSAN MASALAH}

Berdasarkan latar belakang yang sudah diuraikan di atas maka permasalahan yang akan dibahas pada penelitian ini adalah bagaimana analisis fundamental dan teknikal dalam pengambilan keputusan untuk transaksi emas di perdagangan berjangka?

\section{PENGERTIAN BURSA BERJANGKA}

Pasar kontrak berjangka telah ada pada abad pertengahan di Eropa. Pasar ini berkembang karena adanya kebutuhan petani dan perdagangan untuk mengurangi resiko. 
Kontrak berjangka pertama kali muncul sebagai respon atas jatuhnya harga-harga komoditas pertanian pada saat panen raya. Komoditas pertanian seperti gandum, kedelai, kacang, jagung dan biji-bijian lainnya mengaami penurunan yang sangat drastic pada saat panen, akibatnya petani mengalami kerugian yang sangat besar.

Sebagai ilustrasi, petani sering tidak tahu apa yang akan terjadi dengan harga komoditinya pada saat dipanen, jika panen pada umumnya berhasil harga akan turun,tetapi jika ada kegagalan panen, harga akan naik. Pada saat harga turun pedagang akan diuntungkan dan petani merugi, tetapi hal sebaiknya akan terjadi apabila harga naik.

Selain itu banyak diantara negara-negara berkembang yang hanya memiliki produk pertanian tersebut terpaksa harus melakukan berter dengan negara-negara maju untuk produkproduk teknologi tinggi, seperti alat-alat perang, peralatan rumah sakit, obat-obatan, alat transportasi dan kebutuhan dasar lainnya.

Untuk menjembatani barter tersebut dan untuk mempertahankan harga produk pertanian agar petani tudak mengalami kerugian maka dibuat perjanjian atau kontrak jual-beli komoditi pada harga yang telah ditentukan sekarang meskipun penyerahan barang baru akan terjadi di masa yang akan datang, yang kemudian muncul sebagai pasar berjangka produk pertanian yang dikenal sebagai commodity future market.

Selanjutnya, pasar berjangka telah berkembang pesat menjadi semakin penting dalam dunia keuangan dan investasi. Pada umumnya transaksi aktiva riil dan keuangan aktiva di dunia bisnis dikenal dengan sebutan spot atau cash market, dimana aktiva tersebut diserahkan segera atau beberapa hari setelah transaksi terjadi. Pada pasar berjangka penyerahan aktiva riil maupun keuangan yang diperjual-belikan terjadi di masa mendatang pada waktu yang telah disepakati, tetapi harganya ditentukan hari ini.

Menurut UU Nomor 32 Tahun 1997 tentang Perdagangan Berjangka Komoditi sebagai landasan hukum pelaksanaan perdagangan berjangka di Indonesia, perdagangan berjangka (future trading) adalah segala sesuatu yang berkaitan dengan jual beli komoditi atau produk financial yang peyerahannya dilakukan kemudian hari berdasarkan kontrak berjangka atau opsi atas kontrak berjangka.

Perdagangan berjangka berlangsung hanya di pasar-pasar yang terorganisasi atau dikenal sebagai Bursa Berjangka atau Future Market. Pengertian bursa berjangka ini dikemukakan oleh BAPPEBTI ( Badan Pegawas Perdagangan Berjangka Komoditi ), yaitu "Future market is a central marketplace with established rules and regulation where buyers and sellers meet to trade and options on future contracts. "

Oleh karena itu dapat diketahui bahwa bursa berjangka adalah tempat dimana terdapat peraturan dan kebijakan dimana pembeli dan penjual bertemu untuk melakukan transaksi berjangka dan opsi terhadap kontrak berjangka.

\section{INDIKATOR - INDIKATOR DALAM ANALISIS FUNDAMENTAL}

Setiap informasi atau berita yang berhubungan langsung maupun tidak langsung dengan ekonomi dapat merupakan suatu faktor fundamental yang penting untuk dicermati. Berita-berita itu dapat berupa berita yang menyangkut perubahan ekonomi, perubahan tingkat suku bunga, pemilihan presiden, pemberontakan dalam suatu pemerintahan negara, bencana alam, dan lain-lain.

Indkator-indikator dalam analisis fundamental dapat dilihat sebagai berikut :

\section{A. Indikator Politik}

Indikator ini dapat terlihat dalam keadaan politik suatu Negara yang dapat mempengaruhi keadaan perekonomian Negara lain. Contoh : Krisis di zona Eropa, sebelum krisis hutang 
di zona Eropa, mata uang EUR senantiasa kuat dan menekan USD, tetapi setelah terjadi krisis hutang ini yang sampai saat ini belum bias diselesaikan, membuat nilai mata uang EUR terus merosot, dan di prediksi akan terus melemah sebelum krisis di Eropa ini diselesaikan. Begitu juga keadaan keamanan dinegara-negara maju. Misalnya ketika terjadi Tsunami di Jepang, mata uang YEN reatif melemah, dan sangat berpengaruh terhadap transaksi yang terjadi di bursa. Oleh karena itu sangatlah penting mengetahui kondisi keamanan dan politik negara-negara maju yang mata uanganya cenderung mendominasi perdagangan dunia.

B. Indikator Ekonomi

Dalam menganalisa faktor-faktor yang mempengaruhi kondisi fundamental perekonomian suatu Negara, indikator ekonomi adalah salah satu faktor yang tidak dapat dipisahkan dan merupakan bagian penting dari keseluruhan faktor fundamental itu sendiri. Informasi mengenai indikator ekonomi dapat didapatkan melalui beberapa surat kabar seperti The wall Street Journal dan The Financial Times majalah-majalah bisnis, seperti Business Week dan The Economist. Seiring dengan kemajuan di bidang ilmu pengetahuan dan teknologi, untuk mendapatkan sumber informasi terkini (up to date), seorang trader juga sering menggunakan informasi yang berasal dari internet, misalnya melalui Dow Jones, CNBC, Reuters,forexfactory, maupun Blommberg. Dan yang paling lengkap serta selalu update adalah siaran TV internasional CNBC yang berisi semua berita penting yang sedang terjadi di setiap negara besar yang mata uang nya banyak di perdagangkan, serta berita komoditi yang paling terkenal : emas.

\section{ALAT-ALAT DALAM ANALISIS TEKNIKAL}

Analisis teknikal dapat diartikan sebagai salah satu metode pendekatan dalam mengevaluasi pergerakan harga forex. Analisis teknikal didasarkan kepada data-data harga yang dijabarkan dalam bentuk grafik statistika ( monthly, weekly, daily, 8 hours, 4 hours, sampai pergerakan setiap 1 menit) di tambah dengan beberapa indicator lainnya yang dapat digunakan untuk memprediksi harga.

Alat-alat dalam analisis teknikal adalah :

1. Chart

2. Trendline

3. Channel Lines

4. Support Line dan Resistance Line

\section{PENGAMBILAN KEPUTUSAN TRANSAKSI BERDASARKAN ANALISIS TEKNIKAL DAN FUNDAMENTAL}

Analisis teknikal menggunakan grafik untuk melihat pergerakan harga sebelumnya dan memperkirakan pergerakan harga ke depannya. Instumen yang digunakan dalam analisis teknikal ini adalah :

1. Grafik candle stick

Gambar 4.3 : Candlestick 


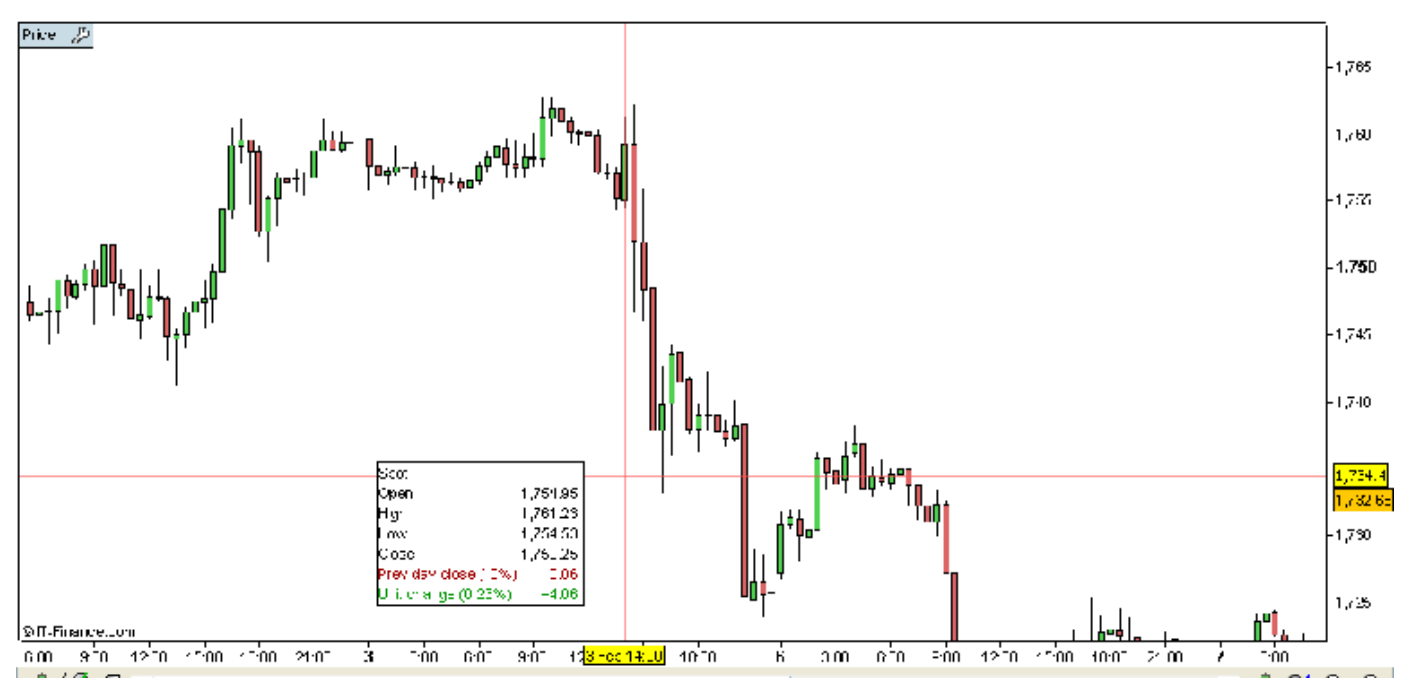

2. Indikator Super Trend

Gambar 4.4 : Super Trend

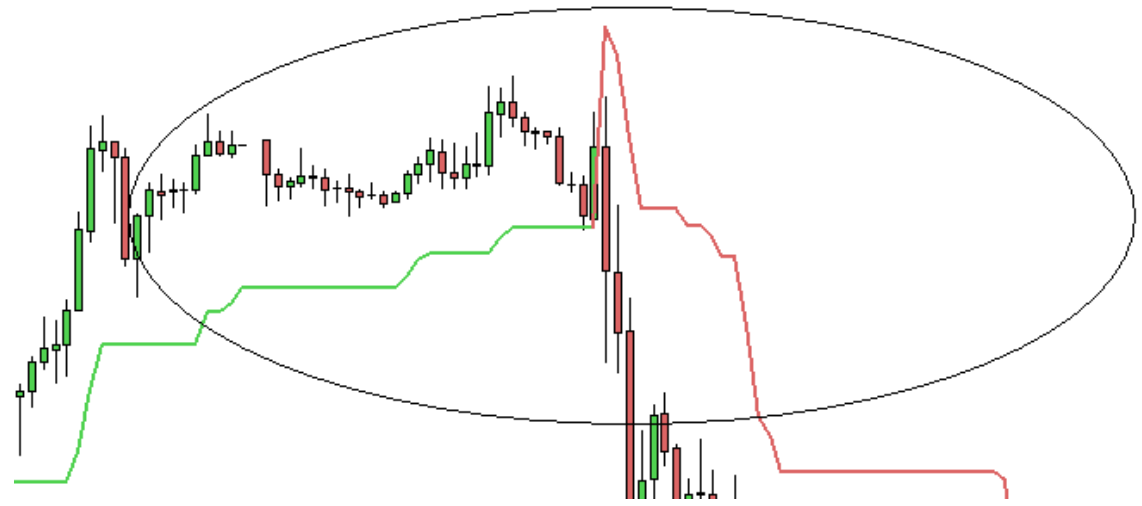

3. Stochastic

Gambar 4.5 : Stochastic

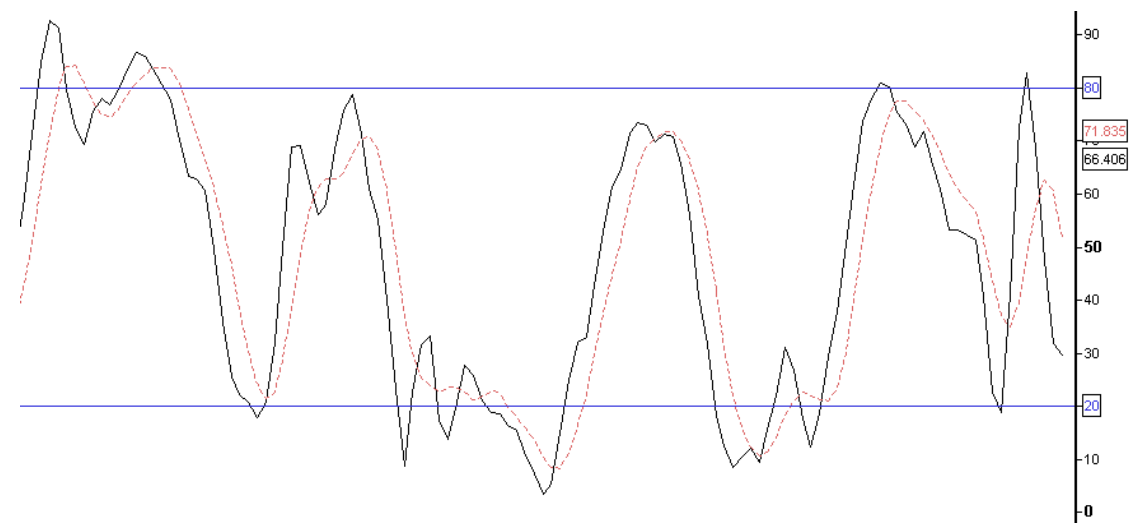


4. MACD

Gambar 4.6 : MACD

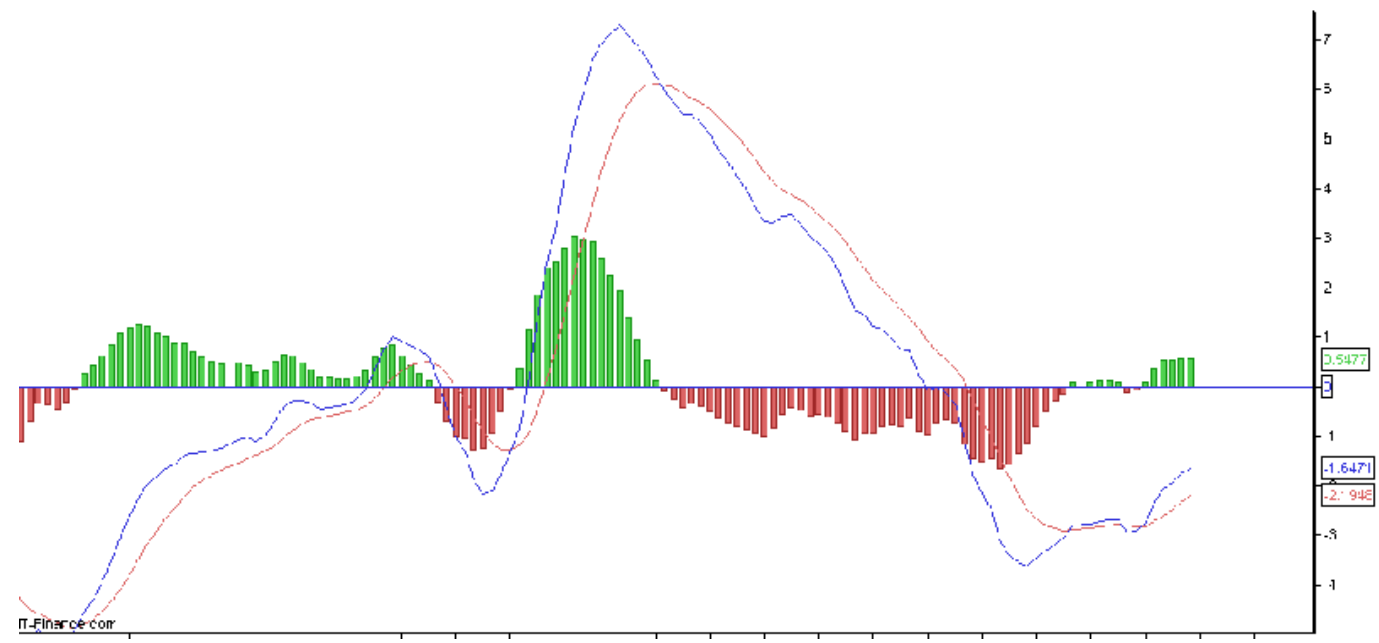

Keempat instrumen di atas di gabungkan dalam penggunaannya untuk melihat pergerakan harga dimasa depan.

Gambar 4.7 : Candlestick, Super Trend, Stochastic, dan MACD

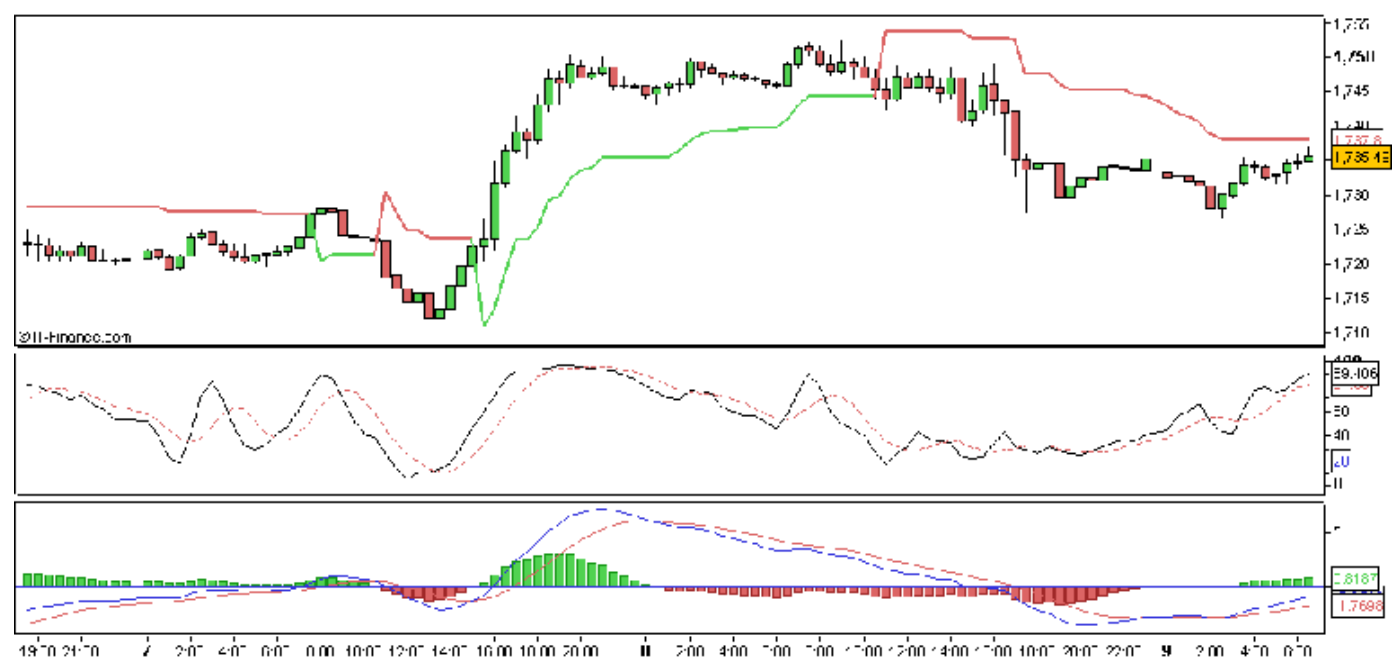

30 menit sebelum berita di rilis harga di buka di 1754.95 USD/oz, saat itu MACD dan Stochastic sudah berada posisi overbought dan mengindikasikan harga akan segera turun. 
Gambar 4.8 : Analisis Grafik

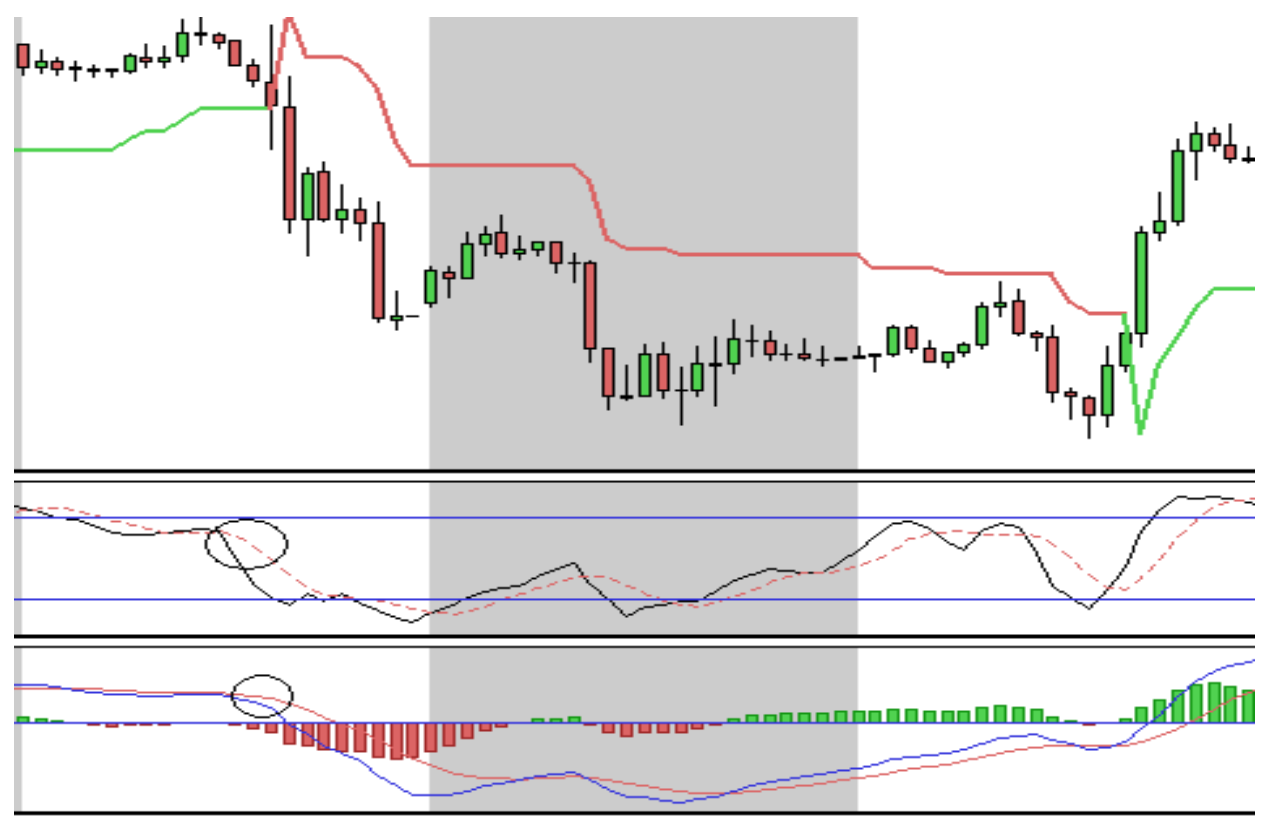

Stochastic pada gambar di atas sudah bersilangan dari atas dan menuju ke bawah, dan MACD pun sudah bersilangan, jugan mengindikasikan trend menuju ke bawah. Berdasarkan hasil analisis teknikal di atas sebaiknya mengambil posisi sell daripada buy.

Berdasarkan hasil analisis fundamental trader mengetahui bahwa hasil berita ekonomi dari Amerika Serikat mempunyai dampak yang baik untuk pertumbuhan perekonomiannya, yaitu peningkatan gaji untuk pegawai di sektor non pertanian, dan menurutnnya persentase tingkat pengangguran dibanding bulan sebelumnya. Kedua hasil yang positif ini secara langsung akan memperkuat indeks harga USD terhadap harga emas sehingga secara langsung membuat harga emas menurun terhadap USD.

Berdasarkan hasil analisis teknikal trader mengetahui bahwa harga sudah berada dititik oversold berdasarkan indikator stochastic dan MACD. Harga sudah cenderung tinggi, menurut indikator MACD dan stochastic harga akan mengalami penyesuaian atau penurunan karena sudah terlalu tinggi, sehingga lebih baik jangan mengambil posisi buy tetapi melakukan transaksi posisi sell yang lebih mempunyai peluang untuk mendapatkan profit berdasarkan grafik.

Berdasarkan hasil kedua analisis fundamental dan teknikal sebaiknya trader melakukan transaksi sell karena baik hasil dari analisis fundamental maupun analisis teknikal menunjukkan bahwa harga akan turun, sehingga kecenderungan untuk mendapatkan profit lebih tinggi ketika melakukan transaksi posisi sell daripada buy.

Selain itu dengan mengambil posisi sell berdasarkan hasil analisis fundamental dan teknikal tersebut, tindakan untuk menerapkan manajemen resiko juga menjadi lebih mudah karena posisi yang di ambil sudah searah dengan trend dan sesuai dengan hasil analisis yang dilakukan. 


\section{SIMPULAN}

Dari uraian diatas penulis membuat beberapa kesimpulan yang diharapkan bisa mewakili inti dari penelitian ini :

1. Analisis fundamental dan teknikal merupakan satu-satunya alat yang paling baik digunakan untuk pengambilan keputusan dalam transaksi emas di perdagangan berjangka.

2. Pengambilan keputusan dalam transaksi emas di perdagangan berjangka minimal harus berdasarkan dari analisis fundamental dan teknikal. Pengambilan keputusan dengan hanya berdasarkan hasil dari salah satu analisis saja bisa sangat fatal akibatnya.

3. Ada berbagai sumber analisis fundamental dan berbagai alat dalam menggunakan analisis teknikal yang dapat di gunakan sebagai alat pengambil keputusan dalam transaksi emas di perdagangan berjangka.

\section{DAFTAR PUSTAKA}

Blocher, Edward J., Kung H. Chen dan Thomas W. Lin. 2007. Manajemen Biaya Dengan Tekanan Stategik, Edisi tiga, Terjemahan Jilid Satu, Jakarta: Salemba Empat.

Blocher, Edward J., Kung H. Chen dan Thomas W. Lin. 2007. Manajemen Biaya Dengan Tekanan Stategik, Edisi tiga, Terjemahan Jilid dua , Jakarta: Salemba Empat.

Charles T, Srikant M.. dan George . 2008. Akuntansi Biaya Dengan Tekanan Manajerial, Edisi keduabelas, Terjemahan Jilid satu , Jakarta: Erlangga.

Dunia, Firdaus. A and Abdullah, Wasilah. 2009. Akuntansi Biaya.Edisi 2. Jakarta: Salemba Empat

Gorrison, Ray H and Eric W, Norren. 2006. Akuntansi Manajerial. Alih Bahasa Nuri Hinduan. Edisi sebelas.Jakarta. Salemba Empat

Islahuzzaman. 2011. Activity Basec Costing, Teori dan Aplikasi. Edisi satu. CV. Bandung, Alfabeta.

Kamaruddin, Ahmad. 2009. Akuntansi Manajemen, Edisi revisi . PT. Raja Grafindo Persada. Jakarta.

Mulyadi, 2007. Activity Based Costing System, Edisi enam, cetakan kedua. UPP STIM YKPN. Yogyakarta 